\title{
Advantages of virtual dermatopathology use in education
}

\section{Eğitimde sanal dermatopatoloji kullanımının avantajları}

\section{(1) Ellen Mooney}

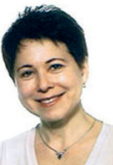

Nordic Institute of Virtual Dermatopathology, Nordurvangi 30, IS-220 Hafnarfjordur, Iceland

\begin{abstract}
The US Food and Drug Administration recently permitted whole-slide imaging systems for primary diagnosis in pathology. Their deliberations and approval process have taken a number of years. However, in the interim, digital pathology has been used in various facets of education, ranging from medical student instruction and assessment, to board examination and continuing medical education. During that time, development in associated software has progressed and now allows for numerous ancillary processes. The advantages in using scanned slides and associated software in education are enormous.
\end{abstract}

Keywords: Whole slide imaging, dermatopathology, virtual dermatpathology, digital dermatopathology, education, continuing medical education, board examination

\section{Öz}

Yakın zamanda, ABD Gıda ve Illaç Dairesi, patolojide primer tanı için bütün slayt görüntüleme sistemine izin verdi. Konunun müzakeresi ve onay süreci birkaç yıl sürdü. Fakat aradaki zamanda, dijital patoloji tıp fakültesi öğrencilerinin eğitim ve değerlendirmesinden uzmanlık sınavına ve sürekli tıp eğitimine kadar eğitimin çeşitli alanlarında kullanıımışır. Bu süre zarfında, ilgili yazılımda ilerlemeler kaydedilmiş olup, artık çok sayıda yardımcı işlemi olanaklı kılmaktadır. Eğitimde taranmış slaytların ve ilgili yazııımın kullanııması çok büyük avantajlar sağlamaktadır.

Anahtar Kelimeler: Bütün slayt görüntüleme, dermatopatoloji, sanal dermatopatoloji, dijital dermatopatoloji, eğitim, sürekli medikal eğitim, heyet incelemesi

\section{Introduction}

April 12, 2017, the Food and Drug Administration permitted marketing of virtual pathology or whole-slide imaging (WSI) systems for digital pathology. A number of studies have been conducted, which confirm the validity and applicability of use of WSI as a diagnostic tool. However, this review will mostly focus on the use of WSI in education, although this form of use is intertwined with other applications of this technique.

\section{Definition}

WSI or virtual pathology is created through software manipulation of digital images of tissue sections, which have been scanned at various magnifications. This enables the viewer to zoom in on areas of interest, thereby simulating the examination of glass slides under a traditional microscope up to magnifications of $\times 40$. The images can then be viewed through specialized software locally or transmitted via a hosting facility through the internet, see Figure 1.

Address for Correspondence/Yazışma Adresi: Ellen Mooney MD, Nordic Institute of Virtual Dermatopathology, Nordurvangi 30, IS-220 Hafnarfjordur, Iceland Phone.: +354 5652178 E-mail: info@nivdp.com Received/Geliș Tarihi: 24.01.2018 Accepted/Kabul Tarihi: 06.02.2018 ORCID ID: orcid.org/0000-0001-9492-5415

c Copyright 2018 by Turkish Society of Dermatology and Venereology

Turkderm-Turkish Archives of Dermatology and Venereology published by Galenos Yayınevi. 


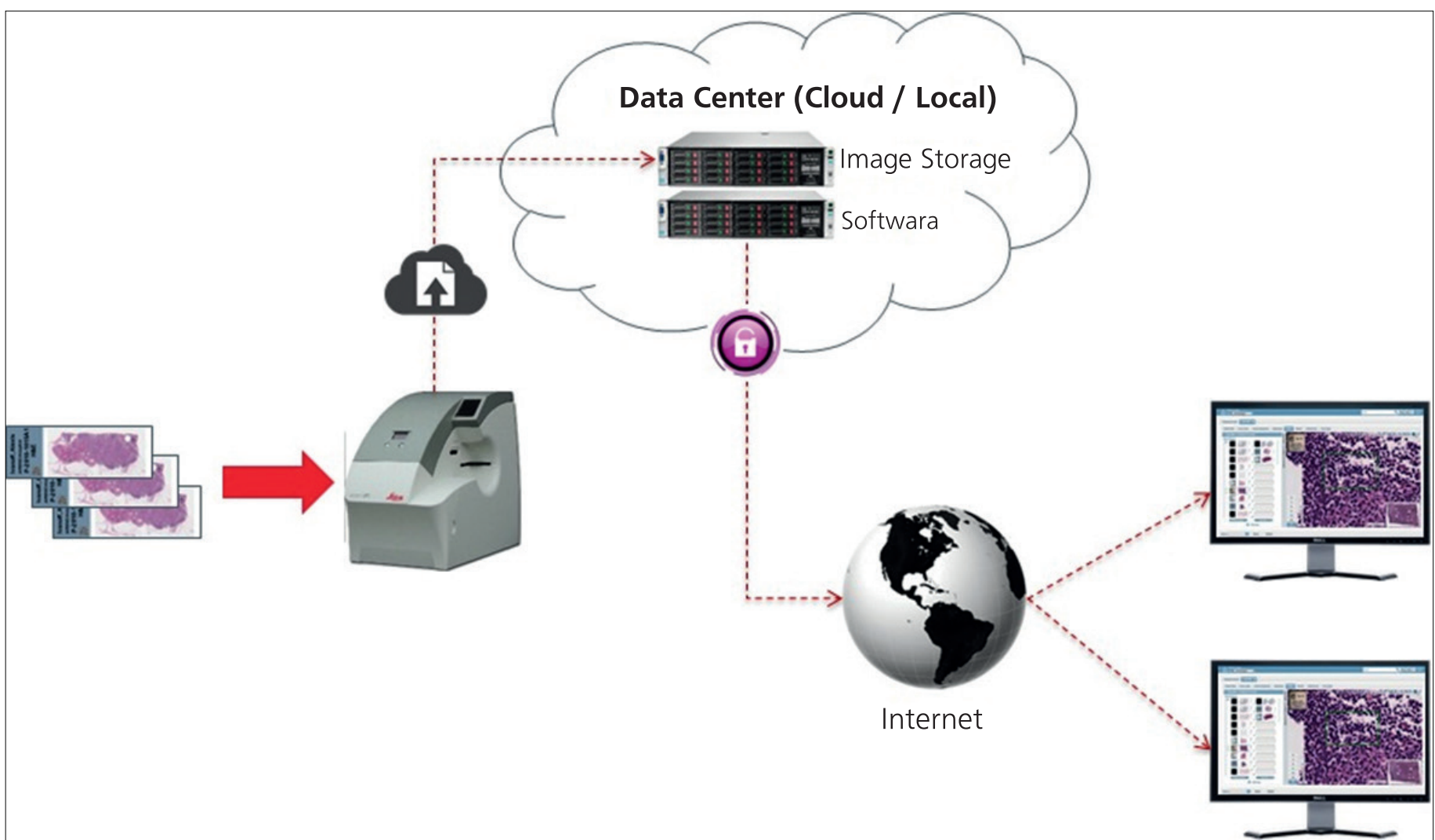

Figure 1. Basic whole-slide imaging sharing. Courtesy of Colin Doolan, BSc. Leica Biosystems

\section{Background research}

Numerous studies have addressed both accuracy of interpretation and workflow efficiency using both small and large numbers of dermatopathological cases. The common denominator has been that diagnoses from whole-slide images were found to be equivalent to diagnoses from glass slides using traditional microscopy ${ }^{1-6}$. A study by a group led by the author also conducted a study comparing diagnostic accuracy with digital slides to photomicrographs and the same results prevailed ${ }^{7}$.

\section{Advantages of whole-slide imaging for use in education}

\section{Storage}

With increasing lack of storage space for glass slides and the risk of depleting tissue blocks for teaching collections, scanning slide collections is of great advantage. It also reduces the time it takes to retrieve teaching slides and collections, thereby saving on manpower. Storage of large banks of slides, and/or software which includes digital slides is most easily achieved in data centers. However, in the case of individual smaller teaching collections, they can be stored on hard drives.

\section{Viewing and equipment cost}

Viewing of WS images occurs without the risk of breaking valuable teaching slides, fading of stains, or the risk of slides being lost in transportation. Thanks to the internet, all participants can view not only the same case, but the same section(s). This ensures that they have access to the exact features of note and this can take place regardless of location and time of day.

By replacing microscopes with computers for viewing slides, there is also reduced cost for equipment and facilities in education-computers are less expensive, take less space and are widely available.

\section{Self-study with associated software}

Software, which allows 360-degree rotation of images, enables viewing in any orientation, including orienting the epidermis at the top, which is valuable in teaching and learning dermatopathology, see Figure 2. In certain software, it is also possible to add annotations, such as circles, arrows, and text boxes for notes, which are quite useful for educational purposes and self-study. In some software, these can be made by each student without being visible to others.

Furthermore, the addition of clinical information and clinical photographs is very useful in learning and teaching clinico-pathological correlation, as well as in consultation and teleconferencing. Finally, creating selfassessment exams, by adding questions, which subsequent to the submission of an answer leads to display of the correct answer, is very useful for self-study. By attaching a discussion, multimedia, web links and references, the usefulness of the images as teaching tools and for continuing medical education (CME) is further enhanced.

\section{Mobile devices and applications}

As distribution of digital pathology ensues, diagnoses will be made with WSI and computers, rather than microscopes, will prevail in educational 


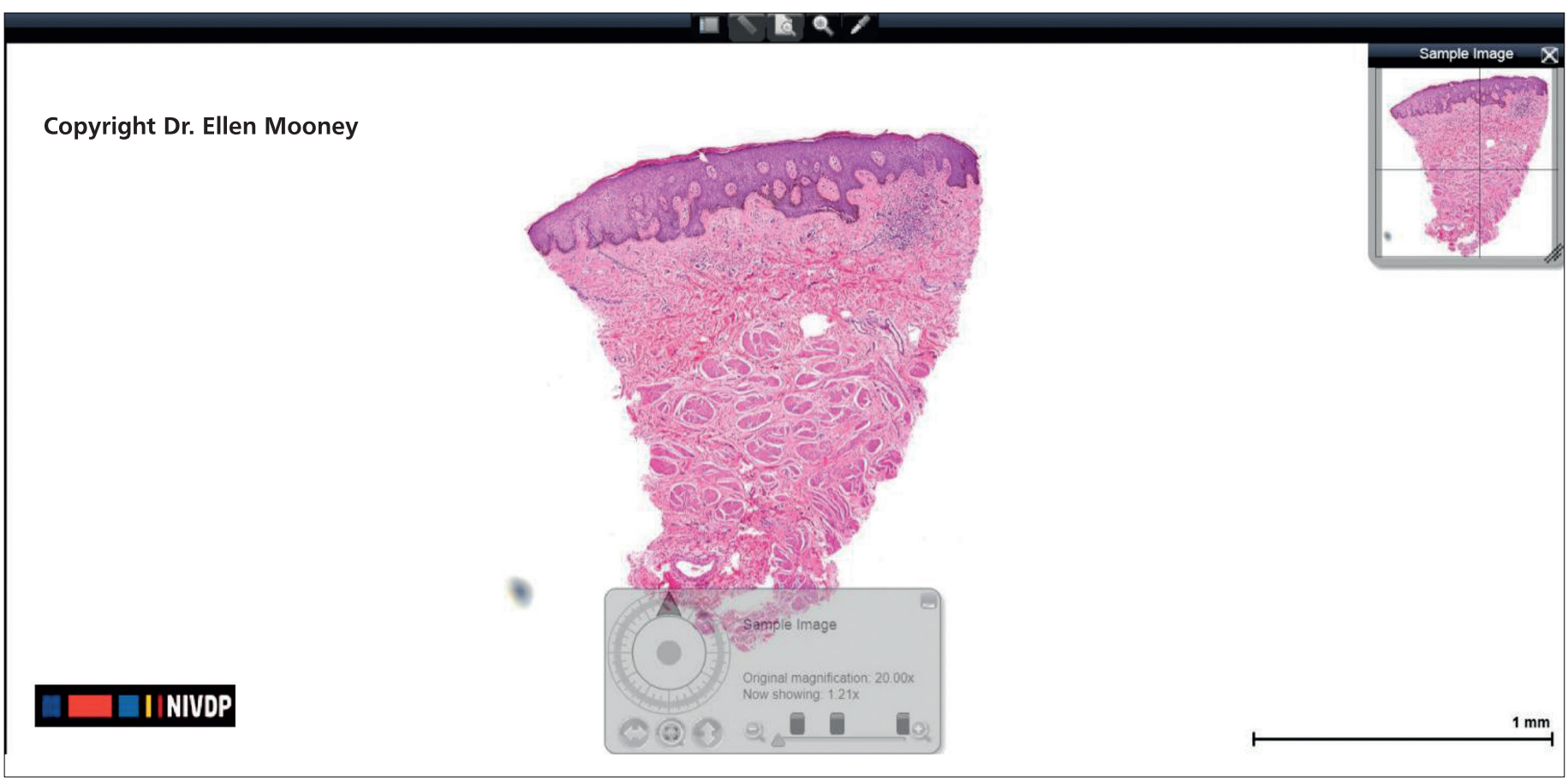

Figure 2. An example of a digital dermatopathological slide can be seen in this link with the use of Adobe Flash Player and a desktop or laptop computer. https://vdpmaterial.nivdp.com/dsb/webViewer.php?snapshotld=1385997412

Use the cursor to move the slide and double click on the image to increase magnification. Alternatively, the control at the bottom of the panel can be used. Supported browsers are Internet Explorer 8 or Google Chrome on Windows, Mozilla FireFox 4 and Safari 5 on Mac (Digital Image. Copyright Ellen Mooney, MD)

settings in universities. Dermatopathological instruction of medical students and training of dermatology residents and dermatopathology fellows will change almost entirely to digital format. As a consequence, applications (apps) for mobile devices, which incorporate digital pathological images for use in education, will become prevalent.

Apps for accessing electronic medical records (EMRs), with links to digital slides, and which can also change the data within the EMRs will be developed. This will result in decreased lag time in both recording diagnoses and therapeutic implementation. Consultation apps will also emerge, making the diagnostic process quicker. Increased clinico-pathologic correlation, due to linking of EMRs to digital slides and the use of apps, will improve both the collaboration between academic dermatologists and dermatopathologists and the training of residents and fellows in dermatopathology. As a result, there will be increased emphasis on clinico-pathologic correlation and therefore, dermatopathological education in dermatology residencies.

\section{Congresses and courses for continuing medical education}

Congresses can also be used as venues for introductory and training courses in the use of digital slide software for consultation. Self-assessment exams have been conducted at congresses in dermatopathology for a few years and doubtless will continue to be used.

The incorporation of examinations with integrated material and multiple-choice questions makes it possible to accrue CME credit online. Accruing CME credit is becoming increasingly important for specialists and it is less expensive and more convenient to do so online. CME is required to maintain medical licenses in the US and provides higher salaries in some European countries. Digital pathology has been proven to be an excellent tool for CME, Continuous Professional Development and External Quality Assurance programs. The American Society of Dermatopathology has a monthly Interactive Case Study using WSI. Independent institutions, such as Nordic Institute of Virtual Dermopathology, also offer The American Medical Association Physician's Recognition Award Category 1 CME Credit for online courses in clinico-pathologic correlation using WSI.

\section{Standardization, certification and re-certification}

Remote consultation with the use of digital slides will lead to the establishment of regional and international networks of dermatopathology, referral centers and/or centers for tertiary care. In order to establish international referral centers for consultation purposes, more equivalency of training requirements and acceptance of board exams across borders will become a necessity.

This will lead to international certification committees and standardization of certification exams worldwide. All of which will be of benefit to patients.

Training Requirements for the Specialty of Dermatology and Venereology: European Standards of Postgraduate Medical Specialist Training have now been approved by the European Union of Medical Specialists. These were created for the European Commissioner for Education and Culture, who is responsible for the preparation of all documents pertaining to recognition of professions in the European Union/European Economic Area. Thereafter, they will be passed to 
the European Parliament for approval. Within an estimated five years, specialists, who wish to move from one European country to another, must pass a European Board Exam in order to have their qualifications approved.

\section{Summary}

The validity and applicability of use of WSI as a diagnostic tool has been substantiated in numerous studies. There are a number of advantages for use of WSI as an educational tool as enumerated in this article. It is useful for teaching and training both in an academic setting and for self-study, for accruing CME, as well as use in certification examinations.

\section{Ethics}

Peer-review: Internally peer-reviewed.

Financial Disclosure: The author declared that this study received no financial support.

\section{References}

1. Kent MN, Olsen TG, Feeser TA, et al: Diagnostic accuracy of virtual pathology vs traditional microscopy in a large dermatopathology study. JAMA Dermatol 2017;153:1285-91.

2. Shah KK, Lehman JS, Gibson LE, Lohse CM, Comfere NI, Wieland CN: Validation of diagnostic accuracy with whole-slide imaging compared with glass slide review in dermtopathology. J Am Acad Dermatol 2016;75:122937.

3. Mooney E: A change that will affect our professional lives and improve patient care. Forum for Nordic Dermato-Venereology 2015;20:43-4.

4. Mooney E, Hood AF, Lampros J, Kempf W, Jemec GB: Comparative diagnostic accuracy in virtual dermatopathology. Skin Res Technol 2011;17:251-5.

5. Leinweber B, Massone C, Kodama K, et al: Teledermatopathology: a controlled study about diagnostic validity and technical requirements for digital transmission. Am J Dermatopathol 2006;28:413-6.

6. Massone C, Soyer HP, Lozzi GP, et al: Feasibility and diagnostic agreement in teledermatopathology using a virtual slide system. Hum Pathol 2007;38:54654

7. Mooney E, Kempf W, Jemec GB, Koch L, Hood A: Diagnostic accuracy in virtual dermatopathology. J Cutan Pathol 2011;39:758-61. 